\title{
Painting, Poetry and the Interference of the Genres in English Art: The Case of William Blake
}

\author{
Atanas Karaçoban ${ }^{ \pm}$and Patricia Denisa Dita ${ }^{¥}$
}

\begin{abstract}
Throughout the history of Western culture and art, there are numerous examples of those who, in their creativity, went beyond the limits of a particular art, embarking instead on attempts to combine in one artistic discourse the practices of various arts, such as music and poetic text, drama and dance, literature and sculpture, literature and painting, and so on. One of these artists is William Blake, acclaimed as a major poet and painter of romanticism in English and world art. He is accredited as the founder of a whole new and original method of producing artistic works, called "illuminated printing", which is a remarkable combination of poetic text, decoration, and picture. Apart from revealing Blake's appurtenance to romantic tradition, the present study aims to present the specificity of his technique and, primary, to disclose the ways in which it combines the artistic practice of poetry with that of painting as to render and strengthen the meaning by mutually sustaining and illuminating each other.
\end{abstract}

Keywords: art; poetry; painting; romanticism; illuminated printing; William Blake.

\section{Introduction: On the Interference of Genres in Culture and Art}

In the context of the critical debate on the issue of the interference between visual art and verbal art, the phrase "visual poetics" implies the fact that there is a connection between these two arts. If we first consider the seventeenth century account of the interference between literary art and painting, we can notice that the two were completely separate from each other, that there was no kinship which might have allowed one to cross from one type of art to another, or at least this was the general thinking when it came to the relation between the two.

In his Laokoön, Lessing claims that the two arts consist of totally different systems of sings. Painting was simultaneous and synchronic, in other words timeless, or all-at-once, or static, whereas literary work was diachronic or distributed in time. In this case, a text has more parts, namely beginning, middle, end, which makes it a process. However, the image is quite different from a text as long as it cannot have beginning, middle or end, but it must capture only the most significant moment. Lessing argues that poetry, being serial or consecutive cannot reach such a target as a painting does, namely the capture of the most important moment only. If a literary text describes the visual, it will fail in achieving that synchronic form of the painting. If the description is not long enough, then it will fail in producing the experience that is offered by the visual. Even though the

\footnotetext{
${ }^{ \pm}$Atanas Karaçoban, Lecturer, Gazi University, Faculty of Fine Arts, Ankara, Turkey. E-mail: akaracoban@gazi.edu.tr.

¥ Patricia Denisa Dita, Lecturer, Bursa Technical University, Department of Foreign Languages, Bursa, Turkey. E-mail: dita.patricia290693@gmail.com.
} 


\section{Painting, Poetry and the Interference of the Genres in English Art}

description is detailed enough, it will still be unable to produce such an experience, as too many details will block the text from achieving the all-at-once form of an image, the simultaneity that characterizes a painting. Reversely, image that consists of unmoving or static features cannot cope with the consecutive character of a text. If a painting attempts to achieve a serial or diachronic form with beginning, middle and end, it will simply become incoherent since it cannot capture so many episodes, but only the most important moment. So as painting has a static form, it makes it impossible for such an entity to spread out or open in time as a text does. Therefore, Lessing considers that these two domains should remain separate.

However, Lessing's opinion does not seem so accurate regarding the "atemporal" characteristic of painting. Of course, paintings stay still and do not move around, and if we think of images and substance and take into consideration Aristotle's notion of the latter which has a stable location, independent self-existence and permanent form, Lessing might have a point regarding the al-atonce form of painting. In nature, substances change. They move, blend or dissolve, but not in the frame. In the frame, substance is still, independently self-existent and permanent. But is this really true for paintings? If we compare paintings to substance, then there might arouse some untrue aspects because even images change. For instance, a painting can have a specific meaning during a period of time, but this meaning can totally change in a decade. However, if we do not consider the meaning of a painting but only the visual experience, image can change in less than a second depending only on the viewer's eye. An individual's each act of looking may capture a different area of the painting at one time, the other parts being disclosed later. These successive glances of the spectator are gathered together through flow of time. One might say that these captures of the different areas of the painting are assembled together creating in the end the final product. However, the following question that arises is if there is indeed a final product created in the viewer's mind. Can someone really reach a totality of a painting as long as the vision is apparently endless? How about the second attempt of looking of the viewer? Can the experience that comes with the second act of looking be different from his first experience? As long as vision is interminable, there is no state of totality of a painting because when we look at a painting we are continuously making corrections or alterations of our previous understanding of the image. Our apprehensions can never repeat themselves entirely, but change, or even get erased and replaced by our new findings with regard to a painting. Hence, is image indeed independently self-existent, static, and permanent or does it simply lack all of these attributions? From my point of view we cannot find these characteristics in the visual art.

Furthermore, macroscopically speaking, a painting can allude to any perception of art embodying a tradition. There are many references in an image, be them willed or not. Therefore, a painting is part of the enormous structure of art tradition from a specific time, a specific doctrine, a certain thought or idea. For example, take the Romantic tenet. In this doctrine there is a thought that the source of poetry is nature, and thus poetry was the imitation of nature. Painting during that time had also its source in nature, and therefore it was also the imitation of nature. Hence, the belief of a possible cross from literature to painting existed everywhere throughout the eighteenth century. Microscopically speaking, in the act of looking, the visual experience does not only imply the fact that the image can change when the viewer gives it another glance, constantly revising it, but also that an individual's interpretation will also connect and correspond to the other paintings he previously encountered. Here we can talk about an "intertextuality" of paintings. But to start with the beginning we shall first consider Roland Barthes's notion of semiotics: 
It appears increasingly difficult to conceive a system of images and objects whose signifieds can exist independently of language: to perceive what a substance signifies is to fall back on the individuation of language: there is no meaning which is not designated, and the world of signifieds is none other than that of language. (Barthes, 1968: 10)

Another question that arises here is if we can focus on the painting only as a painting without thinking of the relation to the world of words. Of course, if we consider what Barthes claims regarding the tendency of all symbolic forms to aspire to the condition of language, we can notice the fact that at some certain point a painting will move out from the world of paintings only to the one of words, namely in that specific moment when an individual will think of an interpretation to the painting or find its equivalent in the verbal. Going back to Lessing's notion of synchronic image and diachronic text, the cross between the fields of the visual and the literary is impossible, or at least very hard. However, if we consider Barthes' claim we start to create a connection between the two, or at least between the visual and the verbal as the language itself. But if we go deeper into Barthes' theories, we can see that what Barthes teaches us with regard to intertextuality in The Death of the Author can be applied to the art of painting as well. Barthes argues that a text is not a line of words releasing a single "theological" meaning (the message of the Author-God) but "a multidimensional space in which a variety of texts, none of them original blend and clash".

Therefore, fragments of text mix, each of them being actually a reflection of the other. The same theory can be applied to paintings as well. If a text can be disconnected from its author, then a painting can be also disconnecting from its frame, deleting in this way the point of origin of the work, now simply belonging to the flowing information.

With respect to the flowing information, in Norman Bryson's article Visual Poetics (1988: 183-193) we can find an explanation to this matter: a text's meaning existing when all the verbal signifiers travel to another signifier; therefore, a text's essence is "moving". Moreover, a text is a multiple object and can exist in many places at the same time. In his article, Bryson mentions Derrida's theory of dissemination, saying that a text has no boundaries, and even though there are titles and prefaces of the literary works, they are only a part of the flow of information travelling in all places across each person. In this case, can painting be similar to a text? Indeed, an image has a discursive aspect - its narrative dimension, its legible structures, its iconography, its connotations and denotations - which can be considered information. Both the verbal and visual arts belong to the universe of information. For a better exemplification, Bryson writes about "colour", which can convey information. If the colour is altered, then the information is altered as well. Therefore, colour can be organized into information, too, as in colour codes. For instance, Guernica is painted pink, thus it implies that its vision of the world might be rosy, because this is the perception we have about this colour.

As we can apply the mobile intertextuality to paintings, it suggests the fact that the interference between literary texts and paintings exists. Moreover, for writers who were painters at the same time, one domain could become an inspiration for the other because in a text one can find such a great description that when read, it instantly creates an image in his mind. Conversely, a painting can be so detailed that even a single moment captured in that image can say the entire story, implying the beginning and the end. 


\section{Painting, Poetry and the Interference of the Genres in English Art}

\section{William Blake, Painter and Poet}

Concerning his career as a painter, William Blake, born in London, never went to school to receive a regular education, never received an ordinary one, his schooling being mainly imparted by his mother, picking up knowledge of foreign languages (French, Italian, Greek and Hebrew) and reading anything coming his way, including the Bible, Shakespeare, Milton, Ben Jonson. In 1767, aged 10, as he had a gift for drawing, he was sent to attend Henry Parr's drawing school, and five years later, in 1772, was apprenticed to the London engraver James Basire, Blake's artistic talent and engraving now combined to become a practical means to earn a living. He stayed with Basire until 1779, when, aged 21, Blake entered the Royal Academy of Arts at Somerset House, where he benefited a lot from its background and facilities, although later he felt restless there, for it seemed that an institution which followed tradition did not suit Blake the artist. His apprenticeship to Basire, however, had already provided him with important artistic experience, especially after he was sent in 1774 to make sketches and drawings of the memorials in Westminster Abbey, when he felt the influence of the gothic art and the fascination of the nude, the latter through a study of Henry Fuseli's translation of Reflections on the Painting and Sculpture of the Greeks by Johann Joseph Winckelmann. At the recently founded Royal Academy, Blake met some of the leading artists of the time, such as Sir Joshua Reynolds and the sculptor John Flaxman, who became his long-time friend. In 1780, he met the Swiss artist Henry Fuseli, who also became his friend, and exhibited a water-color at the Academy. Blake never felt the Royal Academy to be his place, since he rejected classicism as the embodiment of error, as well as the elegant Augustan style, being influenced by the Gothic art, the supreme representation of truth for him, and reading widely from Shakespeare, Milton, Gray, Thompson. In 1787, his 19 year old brother Robert died, and around that time Blake began his long career as an engraver of illustrations to books by others in order to support his family. He illustrated, in 1796, among others, Edward Young's book of poems Night Thoughts, a Wedgwood pottery catalogue in 1815, and, between 1821-1826, an edition of Pastorals of Virgil, Bunyan's Pilgrim's Progress and the Book of Job, and, though little liked at the time, his series of illustrations are powerful and very expressive and especially those for Job are now often considered his masterpiece. Blake also continued to exhibit his own paintings, such as the 1784 exhibition of his drawings at the Royal Academy, the exhibition of a painting on "The Last Supper" at the Academy in 1796, and the 1809 exhibition of the paintings on the "Last Judgment" and other subjects at a London gallery. Two men supported Blake during his life; one was Thomas Butts, who became his long-time patron and from whom he began to receive commissions for various works of art in 1794; another was William Hayley, whom Blake met in 1800 and who helped him financially but who did not fully understand his artistic gifts.

Concerning his career as a writer, Blake started writing plays and poems around the time he was apprenticed to James Basire. His first collection of poetry, Poetical Sketches, which contained such outstanding poems as To the Muses, My Silks and Fine Array, To the Evening Star, Blake himself considering them as no more than attempts to write poetry, was published in 1783 by two of his friends, John Flaxman and Mrs Mathew, who held a different view about them. The volume, containing poems written before he was 21 , and one of them dating even from his twelfth year, was not a success with the public and was not publicly sold. They are said actually to have been written when he was between twelve and fourteen; most of them revealed the influence of Spenser, Elizabethan ballads and songs, and some of them suggested Keats. In 1784 Blake wrote a prose satire entitled An Island in the Moon, and in 1788 published, by illuminated printing, two small 
books representing short sets of prose aphorisms, There Is No Natural Religion and All Religions Are One.

In 1789, Blake inaugurated his special technique of producing art - called "Illuminated printing" - which actually reifies his achievement of combining into one artistic discourse the practices of two distinct arts, poetry and painting. This technique, which he was to use continually during his life on poetry and illuminated editions of his own works, implies that the words and illustrations are engraved, the printed pages are coloured by hand, with each copy slightly different from the others. For this he used copper plates, to strike off the impression of writing on the sheet of paper, and then coloured the page with water-colours by hand: this method was a unique combination of picture, decoration and text, all illuminating one another, but was also responsible for Blake's reduced fame as an artist and poet.

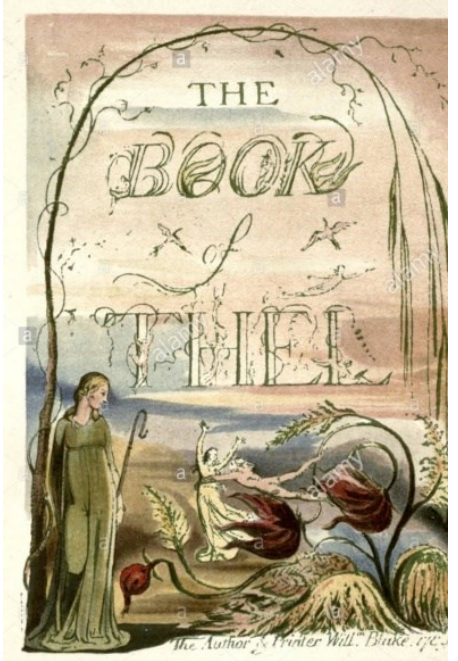

Also, the disadvantage was the small number of issues. The first edition of the Songs of Innocence, for instance, which Blake published in 1798, exist only in 21 copies. In the same year he produced The Book of Thel, which is one of the earliest of so-called Prophetic Books. The Marriage of Heaven and Hell, which rendered the author's own religious views, was written in 1790 (the work contained a series of prose aphorisms entitled "Memorable Fancies" in mockery of Swedenborg's "memorable relations"). Next year he wrote another "prophetic poem", The French Revolution, A Poem in Seven Books, never published during his lifetime, which revealed the author's interest in this great historical event. In 1793, Blake wrote The Visions of the Daughters of Albion and America: a Prophecy, the latter being influenced by the liberation of the American colonies, which would inspire, like the French revolution, the creation of the myths in the later works. Next year Blake added the Songs of Experience to the edition of Songs of Innocence, and of which no separate edition is known (from this time on the two editions are printed together as Songs of Innocence and of Experience Showing the Two Contrary States of the Human Soul, the first collection existing nowadays only in 27 copies). In the same year, Blake also produced and published two other prophetic books, Europe: a Prophecy and The Book of Urizen, the former expressing Blake's own belief in the immediate emancipation through the French Revolution. Another prophetic book is The Four Zoas, which Blake started writing in 1797, but which he never completed. During his stay at Felpham, Blake began composing Milton, A Poem in Two Books, To Justify the Ways of God to Men, completed and engraved between 1803 and 1808. Between 1804 and 1820 Blake composed Jerusalem: The Emanation of the Giant Albion, and his last illuminated work, the play The Ghost of Abel, dedicated to Byron, was published in 1822.

\section{Romanticism and the Representation of Childhood in the Poetry and Painting of William Blake}

Prior to the romantic period, by the seventeenth century, "in English the word "Romantic" had come to mean anything from imaginative or fictitious, to fabulous or downright extravagant. It was often used with overtones of disapproval; as the eighteenth century progressed, however, it was increasingly used with approval, especially in descriptions of pleasing qualities in landscape" 


\section{Painting, Poetry and the Interference of the Genres in English Art}

(Lamont, 1996: 274-275). Following romanticism as a regular literary period and movement, the term continued and still continues to refer to a type of creative writing, but it has also exceeded the literary context, signifying today that type of human personality which is sensitive, emotional, imaginative, instinctual, proud, as well as lonely, escapist, assuming a distance from the others, breaking the contacts with reality, and existing in a universe of his/her own.

According to Petru Golban, "romanticism was a great period of new developments in thought, including literary theory and criticism, and of artistic experimentation in music and poetry, and, to a lesser extent, in drama and fiction" (Golban, 2013: 188). Romanticism spread out initially from Germany, and co-existed with a political revolution in France (acclaimed by the romantics, except the German ones, as providing individual freedom and abolition of the authority) and an industrial revolution in Britain (rejected as a way to human regimentation), as well as with some reactionary political attitudes of the period. Hence, many critics speak about the politics or ideology of romantic literature, regarding it as a social movement:

Setting romanticism in the context of contemporary exchanges about them - and examining such exchanges for what their figures of speech, and sexual allusions, as well as political allusions, may reveal about how the literary work in question accords or conflicts with established discourses and interests - has been a fruitful approach in recent criticism. (Chase, 1993: 31)

However, other critics are reluctant to speak about a romantic ideology in Marxist terms pertaining to the socio-historical position of literature. For them romanticism is first of all a cultural revolution and it is inappropriate to attribute some definite political and social grounds to the new artistic sensibility of romanticism, or to view romanticism as a social or political movement, and the romantic hero as a political rebel. Romanticism is a cultural and artistic movement that refuses to adapt to current social developments; romanticism reacts against the types of thinking which draw on rationalism and reason, namely classicism and the Enlightenment, and, on the whole, the romantic state of dissatisfaction results in the need to pursue and achieve originality, experimentation, and innovation in arts and literature. Also, rather than view romanticism as socially or politically involved, it is more correct to look at the identification of "literature with philosophy [which] appears in Romanticism ... in the emergence of German Romanticism in response to Kant, and in the Jena Romantics' conception of literature as containing its own criticism", and it "has been for Romantics and their readers a way of describing a kind of truth value or truth effect of poetry" (Chase, 1993: 15). Concerning literary theory, the romantic author-critic would focus on art and its product, and on what art is and what it does. There are important critical voices, including that of M. H. Abrams, who consider that romantic writers were "political and social poets", that "to a degree without parallel, even among major Victorian poets, these writers [the romantics] were obsessed with the realities of their era", and that it is "a peculiar injustice that Romanticism is often described as a mode of escapism, an evasion of the shocking changes, violence, and ugliness attending the emergence of the modern industrial and political world" (1970: 101). Harry Blamires unites the views: the romantic age "was an age of revolution, social and technological, philosophical and literary"; nonetheless, he emphasises the socio-economic conditions: "The harnessing of steam-power, the consequent development of mass-production, and the movement of population from rural areas to the growing urban areas of industry of commerce, marked one of the crucial turning-points in modern history" (1991: 217). 
An extremely complex and diverse literary practice and theoretical discourse, there have been continuous and, we should say, successful efforts made to argue that romanticism is a unified movement. Critics stress the unity of romanticism as a remarkably strong cultural tradition, which gave birth within its artistic system to a number of literary concerns (themselves established as traditions) due to the recurrence of certain attitudes, themes, motifs and principles in the writings of many artistic voices. Some of these reveal new feelings for nature and the emphasis placed on imagination, general uses of subjectivity and the concern with the experience of childhood and with the development of the human mind in general. Others constitute the representation of some important psychological issues, while exploring the complexity of the characters' inner world, and the expression of individuality as the most important aspect of human personality. Among those who champion the idea of a unified romantic movement is Rene Wellek with his famous definition of the romantic poets as authors who "see the implication of imagination, symbol, myth and organic nature, and see it as a part of the great endeavour to overcome the split between subject and object, the self and the world, the conscious and the unconscious" (1963: 220), which is the common and central creed of all major romantic writers. To this, we should add the romantic concern with the experience of childhood, which is mingled with a larger and more complex range of approaches and preoccupations, such as the growth of a poet's mind, the act of literary composition, the inner existence and the external, real world, the binary opposition of mind and body (the spiritual and the material), the relationship between man and divinity, the relationship between man and society, and other forms of the dualism of existence; finally, rebelliousness, escapism, and the importance of imagination, emotion, memory, countryside and nature. These aspects are thematically encompassed as notions and principles in the literary works by William Blake, William Wordsworth, Percy Bysshe Shelley, George Gordon, Lord Byron, John Keats, Sir Walter Scott, and others.

Among them, more explicitly dealing with the growth and development of a mature personality is William Blake in Songs of Innocence and of Experience Showing the Two Contrary States of the Human Soul (1794). The poems from the volume render actually the voices of innocence and of experience which belong mostly to children, and Blake is firstly approached in critical studies so far as he revealed in a number of poems and its illustrations from this volume an intense conviction of the importance of childhood in the general development of human personality, a special concern with the universe of childhood, the condition of the child, his place in a world governed by mature principles, all these in close relationship with the writer's attempt to touch the problems of religion, the relationship between man's religious attitude, power of knowledge, and his Poetic or Prophetic capacity (a concept introduced by Blake in There Is No Natural Religion, 1788), the last three aspects being actually explored to a greater or lesser extent in all his work.

This volume, as most of Blake's poetry, was not published in the ordinary way, but engraved or etched by Blake himself on copper plates, with accompanying designs. Design and text were cut in relief, stamped on paper, and then coloured by hand. The Songs of Innocence were first engraved in 1789; the Songs of Experience in 1794. The Songs of Experience were never issued separately, but always with the Songs of Innocence, the two collections having the subtitle: Showing the Two Contrary States of the Human Soul. Many of the Songs of Innocence have counterparts in the Songs of Experience, the relationship being indicated either by a common title, as with Holy Thursday, The Chimney Sweeper, and Nurse's Song, or by contrasting titles, as with The Lamb and The Tiger, The Divine Image and The Human Abstract, Infant Joy and Infant Sorrow (many poems from the 


\section{Painting, Poetry and the Interference of the Genres in English Art}

Songs of Experience represent comments on Songs of Innocence; they are, eventually, satires on the latter set, and many of the poems in both sets are symmetrical and set against each other not only in the thematic implication, but also in the language and stanza form).

The poems from the volume are contrary, not opposite, and highly interrelated; they show the state of man before the Fall (The Edenic state) and the state after the Fall, but the "two contrary states of the human soul' suggest 'not only a failing away from Edenic innocence to experience, but also the possibility of progress towards a Christ-inspired 'higher' innocence and a future regain of paradise" (Sanders, 1994: 353). "Innocence" is the ideal or Paradisal world of protection and peace which the child assumes in the world he is born into; "experience" is the actual world. During childhood the innocence is prolonged, children and young men become characters in Blake's poetic enterprise, the poet himself answers a request of a child "on a cloud" to write the songs: "And I made a rural pen, / And I stain'd the water dear, / And I wrote my happy songs / Every child may joy to hear".

The first set of poems "is an evocation of that paradise which Milton declared lost", and Blake located innocence and purity of humanity not in the childhood of the race, "but in the individual's childhood" (Rogers, 1996: 280). The art of painting as employed by Blake the poet-painter only strengthens this thematic perspective.

The Chimney Sweeper from the first set of poems yet reveals a drama of childhood experience: the boy's mother died when he was very young and his father, unable to support him, put him in a workhouse to the care of officials. The poem may be viewed as a protest against the way children were treated and bereaved of childhood; at that time in England, children were employed as sweepers: they were cheap and small, and "weep" is actually "sweep", for the little boy could not talk properly, and Blake is ironic here. Also, the same interplay of the two colours as concepts is implicitly prompted in the poem: soot, "coffins of black", darkness in the morning - the concept of the conventional, real existence - are opposed to "white hair", "white children", "bright key" - representing the concept of a dreamlike, visionary, non-real existence. The chimney sweepers are "locked up in coffins of black" (which is the space of the chimney, a symbol of death or prison), but Tom's vision changes the life of children, for only imagination and the refuge provided by a

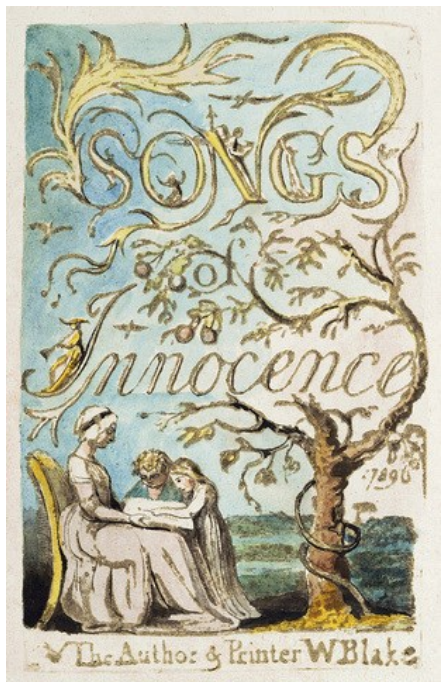
subconscious need for escapism materialized in dream can compensate for the misery of reality and offer spiritual joy.

Imagination, for Blake, is "the real and eternal world of which this vegetable universe is but a faint shadow, and in which we shall live in our eternal or imaginative bodies when these vegetable mortal bodies are no more" (Jerusalem, 77). The dream, passing through the child's mind, leaves its prints in his consciousness, thus forming an illusion of an ideal reality (sleep is a superior form of existence, says, among others, Lucian Blaga). But it seems that Blake draws a clear demarcation line between the two seemingly equal notions of the ideal and the dream: the first is to be never attained, touched or grasped, thus representing a highly abstract transformation of the thought or idea; the second, being abstract as well, inclines to a more concrete realization, which is the mental fulfilment on the conscious level of the human psyche of a hidden and obsessive wish, and the later 
relief: "Though the morning was cold, Tom was happy and warm". The boy's dream may be also viewed as a simple manifestation in sleep of a story he may have been told about a better life after death.

Taking The Chimney Sweeper from Songs of Innocence in the context of romantic views on art, the poet prompts another interpretation:

[it] is first and foremost a remarkable expression of the romantic dualism of existence: in the non-reality of a dream, children live their childhood against the misery of their real existence, in which they suffer and must work, and for that reason are bereaved of childhood; in dream, however, they can accomplish the subconscious need for childhood and escapism based on their self-assumed, and at the same time imposed by the real and adult world, belief in an eventual reward, after death, for the whole of earthly suffering. And what would be the best "reward" for a child other than to be a child, to live his/her childhood? (Golban, 2018: 234)

The child may be a limited reasoner, he may not be entirely aware of his miserable life, as we, the readers, are, but he can see angels and possesses a direct way of access to the world of God. To notice that Blake, even if he reveals some special insights into the experience of childhood and the psychology of children, or his lyrical I takes the posture of a child and his poems are utterances not of the author but of the characters he created, looks at them from a grown-up point of view and

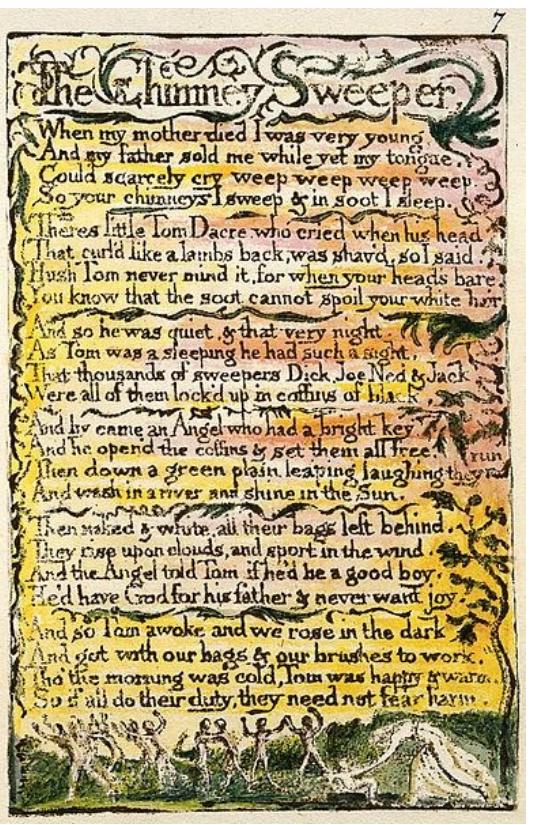
mentality, hence the last moralizing note: "So if all do their duty, they need not fear harm". However, one may regard it as being ironic, given Blake's attitude of disgust towards what he viewed as a fallacious system of morality perpetuated by the false church of the fallen world, the great error of religion (in The Human Abstract this aspect has its symbol in the Tree of Mystery, which is the Tree of Knowledge of Good and Evil), and it seems that he does not shape expressively the indivisible unity, as in Wordsworth, of God, Nature and Human / Child.

Yet in another poem from this set, Holy Thursday, with its solemn, ceremonious verse, showing how pure children are brought to the ceremony of the fortieth day after the resurrection of Christ at St. Paul's cathedral, the lyrical I urges to cherish pity, to welcome any stranger, who might be a missionary from heaven, "lest you drive an angel from your door". The art of painting is again used to make meaning clearer and its impact on reader stronger.

An ironic comment on Holy Thursday is provided by the poem with the same title from the Songs of Experience, which shows that people profit either materially or spiritually by capitalizing on their charity. It seems that the lyrical I passed through experience: for him the Edenic season is spring, the sun - a symbol of imagination and light, the rain and the rainbow - a hope for a better world, different from our way of living, with its poverty, man's dependence on the material needs, a place where "sun does never shine" and "fields are bleak and bare"; instead, he is seeking a better 
place for children, which will be like heaven: "For where-e'er the sun does shine, / And where-e'er the rain does fall, / Babe can never hunger there, / Nor poverty the mind appal".

The poems from the first set represent a vehicle for the author to proclaim eternal love, hope and joy for everyone, but the succeeding Songs of Experience on the contrary declare such dreams

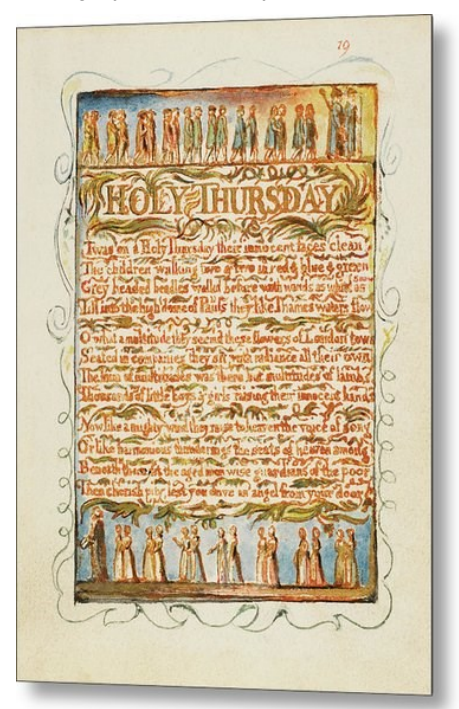
as utopian and childish. Blake is aware of the terror and hostility of the conventional adult society in the face of some features of the child's outlook, for the child and the young adult are impeded by social and religious oppression, with a sickly conscience of it. The illustrations accompanying the poems show death, weeping, menace and desolation; also the tone is more varied: it may be one of angry protest, as in Holy Thursday, or of cynical reasoning, characteristic of the world of experience, as in The Human Abstract and The Chimney Sweeper. The latter, set against the poem with the same title from the Songs of Innocence, is essentially a dialogue, in which the degree of tragedy is extended ("A little black thing among the snow", "They closed me in the clothes of death", and so on), but the idea that a child is pure and innocent, his misery is the way of access to heaven, and that he needs no earthly institutions of God, church, priest, king (while his parents, who got the experience, have to pray for this access) is preserved.

Innocence is equated with purity, saintliness and can be regarded as the spiritual, dream-like existence; experience, with its abstract rationality and firm general principles, even if inferior to innocence as a state of being, is a necessary aspect of human personality, be that human a child or a grown-up (the latter idea clearly stands in front of other ideas in the above mentioned The Chimney Sweeper from Songs of Experience, a poem with a far greater satirical, even sarcastic, edge). Thus Blake's lyrical hero is far from contemplating the scene of misery, he is indignant and revolts at the unjust and undeserved destiny, condemning regimentation and exploitation, all these being linked to the immense change in his mind and way of perceiving the external world, which compelled the transformation of his attitudes. Now an experienced observer, and not the small chimney sweeper starts the first stanza of the poem, uttering the striking words of truth at the end of it, words that are coming out of the child's mouth and are linked to his mental conviction of the illusion of a better existence, thus rejecting his own universe of escapism:

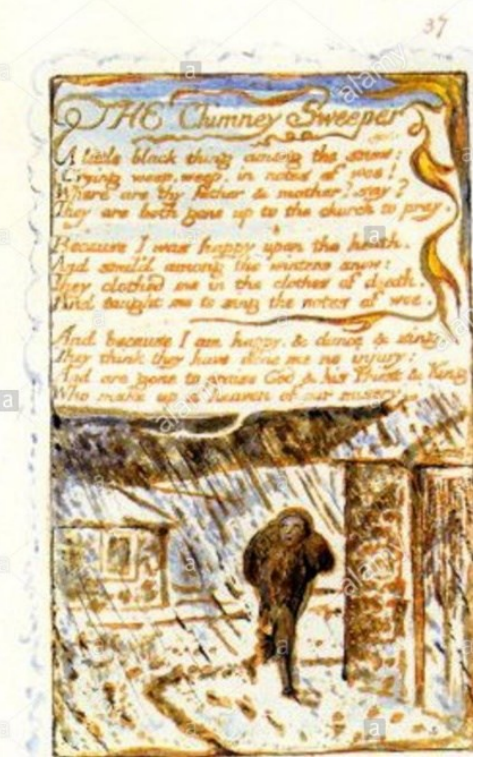
"And are gone to praise God and his Priest and King, / Who make up a heaven of our misery".

Despite their hymn-like simplicity and their nursery-rhyme rhythms, their simple language and their relatively direct utterance, Blake's Songs reveal a remarkably complex range of meanings, symbols and poetic devices sparked off by again plain and common poetic material which consists in descriptions of the condition of children, the contact and conflict of the old with the young. In this respect - and also being conscious of the fact that the poems from both sets escape the limited 
universe of childhood due to their comprehensive nature of meanings and symbols, some of which are beyond children's apprehension, for a child is not able to understand or understands them improperly - one may mention the poem Infant Sorrow from the Songs of Experience, which renders the protest of the child at birth, its first experience of danger and violence of the exterior mature world:

My mother groan'd! My father wept.

Into a dangerous world I leapt:

Helpless, naked, piping loud:

Like a fiend hid in a cloud.

Struggling in my father's hands,

Striving against my swaddling bands,

Bound and weary I thought best

To sulk upon my mother's breast.

The illustration, again, assists and enhances the thematization of the poetic message:

Most explicitly the theme of childhood is rendered by Blake's own conviction that the child is primarily an aspect or possibility of every human personality. The greater part of his writing bears witness to the individual testing of the wisdom, morality and theology of his time, sometimes the author being amused when regarding the church - the dwelling place of God on earth - as the shortest distance between the Holy Spirit and innocence, sometimes rendering the value of strong emotion, notably anger, as the tool or weapon of a healthy mind. The latter aspect clearly stands in front of others in the works in which Blake renders the way children are bereaved of childhood, and, without any parental guide, they become intellectually weak (for instance when no one can answer their questions that are linked to their own attempt to discover the world). Blake himself reveals his own need to focus on the mental type of

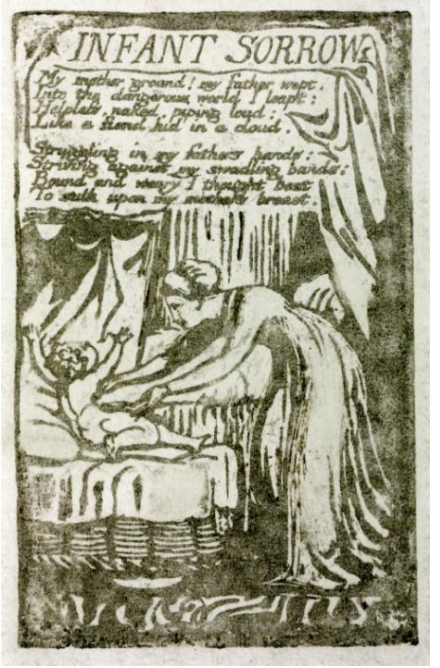
starvation which, if not dealt with, may lead to retardation and a tragic waste of human potential: "His child characters seem to be disturbed in their early life, thus having difficulties in coping with other people, especially when concepts and principles of their specific thinking met with in daily existence become more abstract, as does their thinking" (Golban, 2003: 58).

These and other issues as well as their effects on human personality are the ultimate material of his symbolic Prophetic Books too, but in the short poems of Songs of Innocence and of Experience Showing the Two Contrary States of the Human Soul they receive a clearer statement. Also, the poems from Songs of Innocence and of Experience constitute a definite and particular part of Blake's literary work, but many of their recurrent symbols and motives are present also in his other poems, particularly those called Prophetic Books. 


\section{William Blake and His Mythopoetic Imagination in Prophetic Books}

The Prophetic Books represent a series of poems rooted in Blake's own interpretation of the Bible, his readings in Gnosticism, and his interest in the doctrine of the Swedish philosopher Emmanuel Swedenborg. In these poems and in their accompanying illustrations, Blake attempted to transmit a personal mythology coloured with obscurity and a cloudy idiom alien to his contemporary audience's mentality, an obscurity Blake made no efforts to dissipate, claiming that "What is Grand is necessary obscure to weak men". This is another reason of Blake's reduced fame during his lifetime, and he was almost unknown to poets like Wordsworth and Coleridge, even though his passion for freedom, his revolt and struggle against the convention, his personality of a natural rebel resembles those of the other English romantic writers, especially those of Byron and Shelley.

The Prophetic Books constitute a unique pattern of a four-dimensional universe created by what has been often called Blake's uncommon "mythopoetic imagination". The four dimensions represent four contrary principles which coexist and are complementary and necessary to each other, just as eternity and the material world as man's fallen state. They are presented as mythological creatures governing the universe, receiving in the poem with the same title the name of the "Four Zoas". They are assigned compass points emerging in the world in an anticlockwise cycle starting from the west. They are given specific names and correspond to the four aspects of Divinity: Tharmas, representing body or sensation, is God the Father, Luvah, representing emotion, is God the Son, Jesus; Urthona, who stands for imagination, is the Holy Spirit; Urizen, who stands for reason, is the Angry God, the fallen part of Divinity, Satan, the "God of this world".

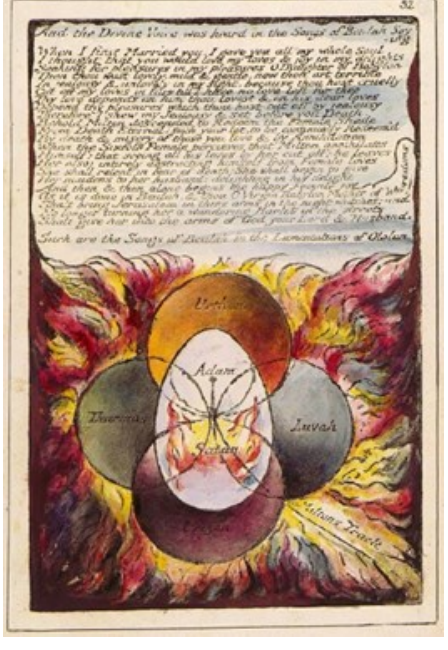

Blake tells their individual stories, as well as the stories of their fallen forms and their female counterparts in The Book of Urizen, The Book of Los, The Book of Ahanis and in other poems. Los is viewed as the fallen form of Urthona, sometimes identified with Satan, described in the The Song of Los as the "Eternal Prophet". Los also represents the Time and the Artist, gradually changing during the evolution of Blake's mythology, finally, in Jerusalem, becoming a strong force of energy, though morally ambiguous. He is usually rendered antagonistic to Urizen, in his role of a blacksmith (as Roman Vulcan) binding Urizen in iron links, and, in the earlier poems of the cycle, binding his own son, the rebellious Orc. His female counterpart is Enitharmon, his periods of estrangement from her turning disastrous for the stability of the universe.

Urizen, along with Los, is the principal character of Blake's prophetic books, a symbolic, complex and ambiguous figure. In the first plate of Europe, he is portrayed as a Newtonian figure leaning down from the sun with a pair of compasses to create the world, where the art of painting is again revelatory in this sense.

In The Book of Urizen, a work displaying a strong and intense sense of anguish and revolt, Blake actually describes the creation of the material world by Urizen, thus providing his own version of the Genesis. 
The world is created from the "abominable void", from which Los, the opponent of Urizen, and Pity, the first female form, named Enitharmon (Inspiration and Space), emerge. Urizen is also the creator of the Tyger, the law-maker; he is actually associated with the law as the restricting power of society and morality; as God of reason, he is responsible of the tragic finitude

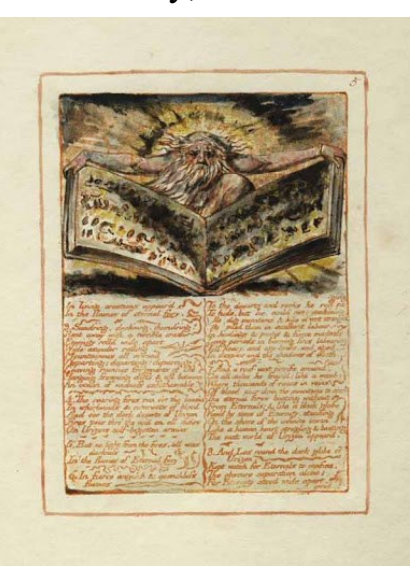
of man, for the power of reason traps him within the five senses and produces only the limited dimensions of time and space. In another prophetic book, America: $A$ Prophecy, Urizen is the symbol of all repressive codes, and is opposed to the struggle of America with England. Opposed to Urizen here is Orc, the symbol of rebellion and love of freedom, described as "Lover of Wild Rebellion, and transgressor of God's Law".

The artistic conception of William Blake, though never presented in any theoretical writing, finds its expression in the artistic activity - both literature and painting - of the romantic author. His creation is highly original and personal; however, he is viewed as the first representative of the English romantic movement, the first romantic poet and painter in English literature. Considered a religious poet, Blake was not attached to the traditional dogmas, not orthodox, as we understand nowadays the meaning of this word. He developed his own religious system by his own interpretation of the Bible, was interested in the Celtic revival of his age, and was influenced by the works of the Gnostic authors, who believed in the revelation of science, and by the mystic and spiritualist doctrine of Emmanuel Swedenborg, the author of the Universe of Spiritual

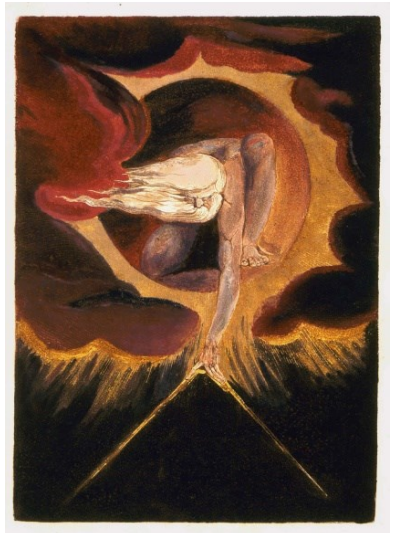
Structure. These aspects constitute the main sources of the strange cosmogony and mythology of his Prophetic Books. He also claimed that in 1761 he saw God "put his head against the window", which is the first of many religious visions he would experience. The nature of these visionary experiences is regarded by Blake as being the way of access to the ultimate truths of the universe, and is more or less explored in his entire literary activity. Blake constantly and repeatedly pretended to have had visions, enforcing the visionary characteristic of his work. These peculiarities and characteristics of his life and nature made him the author of a strange, unique but impressive work; they contributed to his own personality as an artist, singular and hardly fitting in the cultural pattern of his own time, and it was not until the first half of the twentieth century that his place in the development of English painting and literature was totally recognized.

\section{Conclusion}

According to Blake, the artistic creativity is linked to the "Poetic or Prophetic" capacity of man - they are actually equated, for the poet is also a seer, a prophet - and man's power of knowledge and religious conception. Blake also focuses on the opposition between the spiritual world of imagination and the frustrations of corporeality, often implying death as the only solution to escape 
the fleshly, material existence. The Book of Thel renders the Neoplatonist idea that being born in the world of senses confines man in the five senses, limiting his capacity for perception. Blake creates a religion of imagination which aims at rebuilding the oneness and wholeness of man and his comprehension of the relationship between the human being and the universe. In Jerusalem, Blake defines imagination as the noblest of human powers, opposing the "Daughters of Memory" to the "Daughters of Inspiration", which is tradition to the originality of the creative act, claiming that "Imagination has nothing to do with Memory", while the material world is important in so far as it stimulates the "divine arts of Imagination".

The "man of mist and fire", as Swinburne called him, William Blake ranks today with the names of Chaucer, Shakespeare and Milton, and holds a special place in the history of literature and that of painting. Like Wordsworth, Keats, Byron and other English Romantic artists, Blake felt the significance of childhood experience, but unlike Wordsworth-participator with stronger psychological insights into the experience of childhood, for instance, Blake-contemplator pictures to the reader a number of aspects of the experience of childhood without suggesting focusing the reader's attention on the sharp psychological conflict in individual minds. What Blake's poetry and painting do, is allow the audience to contemplate with him the facts in their emotional intensity, or the conflict between innocence and experience, and to share his complex attitude on terror, sorrow, admiration or inquiry. He is also dealing with the psychological and moral problems of us all, those that are inescapable in family life and in the contact and conflict of the mature mind of experience with the infantile one of innocence and purity.

\section{References}

Abrams, M. H. (1970). English Romanticism: The Spirit of the Age. Romanticism and Consciousness: Essays in Criticism. Ed. H. Bloom. New York: W. W. Norton and Company.

Barthes, R. (1968). Elements of Semiology. Boston: Farrar, Straus and Giroux.

Blamires, H. (1991). A History of Literary Criticism. London: Macmillan. https://doi.org/10.1007/978-1-34921495-2.

Bryson, N. (1988). Visual Poetics. Pennsylvania: Penn State University Press.

Chase, C. (1993). Romanticism. London: Longman.

Golban, P. (2003). The Victorian Bildungsroman. Kutahya: Dumlupinar University Publishing House.

Golban, P. (2013). The Foundations of English Literary Criticism: From Philip Sidney to Henry James. Lewiston: The Edwin Mellen Press.

Golban, P. (2018). A History of the Bildungsroman: From Ancient Beginnings to Romanticism. Newcastle upon Tyne: Cambridge Scholars Publishing.

Lamont, C. (1996). The Romantic Period. The Oxford Illustrated History of English Literature. Ed. P. Rogers. Oxford: Oxford University Press.

Mitchell, T. (1982). Blake's Composite Art: A Study of the Illuminated Poetry. New Jersey: Princeton University Press.

Rogers, P. (1996). The Oxford Illustrated History of English Literature. Oxford: Oxford University Press. Sanders, A. (1994). The Short Oxford History of English Literature. Oxford: Clarendon Press.

Wellek, R. (1963). Concepts of Criticism. London: Yale University Press. 